\title{
A framework of significant human resource management practices in Vietnam
}

\author{
TRAN KIM DUNG \\ University of Economics HCMC - tkd@ueh.edu.vn \\ TRUONG THI LAN ANH \\ Institute of Management and Technology Promotion - anhttl@imt.vn
}

ARTICLE INFO

Article history:

Received:

Mar. 21, 2017

Received in revised form:

July 04, 2017

Accepted:

Oct. 25,2017

Keywords:

Business performance

Human resource management practices

Vietnam

\section{ABSTRACT}

This paper aims at conceptualizing a framework of human resource management practices (HRMPs) that will work effectively in Vietnam. qualitative research is applied, based on a survey of 388 companies located in Ho Chi Minh city, Vietnam. HRMPs in Vietnam can be measured using seven criteria. Apart from the four traditional HRM functions, which are recruitment selection, training development, performance appraisal and compensation, HRMPs in the Vietnamese context involve three additional criteria: leading change and motivation, both based on traditional soft practices, and talent management, which is based on contemporary hard practice. The validity and reliability of the HRMPs has been confirmed. It was found that the role of HRMPs explains 43 per cent of the variation in a firm's business performance. The findings imply that HRMPs in Vietnam, despite lagging behind global trends, are on track to catch up with them. The trend of adopting HRMPs in Vietnam continues with the emergence of traditional HRM soft practices and contemporary HRM hard practices. The typical framework of most common HRMPs in Vietnam implies that there is a need to design appropriate training programs for both HR professionals and line managers. 


\section{Introduction}

Traditionally, human resource management practices (HRMPs) have focused only on the factors that distinguished the HRM functions from the other functions of a firm. Thus, the most common topics examined in HRM studies include recruitment and selection, training and development, performance appraisal, compensation and benefits, work relations, employment law and compliance (Ying, 2005). These practices emphasize both the hard and the soft functions of HRM, which normally come under the accountability of HR departments. However, the common vision expressed recently by 64 thought leaders in this field (see Losey et al., 2005) is that the traditional HRM functions are not sufficient and that HR in the twenty-first century needs to be integrated into core organizational processes. Given the changing role of HRM today, the HR department of a firm needs to work in partnership with its line managers. In return, line managers need to take direct responsibility for HRM under their supervision, and contemporary HRMPs - both hard and soft - should be introduced to meet the requirements of this changing role.

Research into HRMPs has increased in recent years as HR transformation has diffused from developed to developing countries. However, the research has discretely measured or analyzed HRMPs, without a conceptual framework to attempt to connect the roles of the different HRMPs or to reflect on their interrelationships. This study focuses on drawing out connections among the hard and soft HRMPs, and among the traditional and contemporary HRMPs. This enables us to identify possible trends in the evolution of HRMPs within Vietnamese enterprises. Since Vietnam joined the World Trade Organization (WTO) and the Trans-Pacific Strategic Economic Partnership
Agreement (TPP), many changes have been undertaken in the HRMPs of Vietnamese firms. HRM has become the responsibility not only of the HRM departments, but of all line managers. This paper investigates a new framework that is suitable for HRMPs in Vietnam after nearly 30 years of economic reform and open-door policies.

The objectives of this research are to:

(i) conceptualize a framework for HRMPs that reflects their typical characteristics and their inter-relationships in the development of HRM in Vietnam;

(ii) identify the dimensions of the HRMPs that are commonly implemented in Vietnam;

(iii) examine the overall impact of HRMPs on the Vietnamese firms' business performance.

Preliminary research was conducted using qualitative methods to explore the current HRMPs in Vietnam. Qualitative research was undertaken, based on a survey of 388 companies located in Ho Chi Minh city, Vietnam. Construct validity of HRM practices then was tested. Their relationships with business performance are examined to determine which HRMPs are significant in Vietnam.

\section{Literature review}

\subsection{The concept of human resource management}

Due to the importance of HRM, there is a considerable volume of research. With the evolution of the HRM concept, its terminology has varied such as personnel management, HRM, strategic HRM, people management, human capital, people capital, etc. which in turn causes diversity in HRM functions and practices. Approaching more with the eventual aim of HRM, Noe et al. (2016) emphasized the policies, practices, and systems that influence employees' 
behavior, attitudes, and performance. The later definitions the more concern on the strategic and humanistic roles of HRM as a trend for sustainable development of the organization. Discussing the trend of HRM, Ulrich et al. (2012) argued that business strategy should no longer be a consequence of what HR should focus on. In return, HR should look further the strategy to the outside world and proactively contribute to the designing of business strategy for a sustainable development.

As in other developing countries, many managers in Vietnamese firms just focus on developing markets and reducing costs and not on developing their people and improving their satisfaction. Especially in many Vietnamese small-and-medium enterprises (SMEs) and stateowned enterprises (SOEs), managers hesitate to apply the concept of "human resources" as they mistakenly perceive that the term refers to the government's responsibility (Tran, 2015).

Line managers tend to blame HR department for any shortages of their people, both in terms of number and qualification. They act toward the HRM functions as outsiders without any related responsibility. When receiving such complaints, CEOs simply send those who lack professional capabilities in technology, marketing, finance, etc. back to the HR department without any concern about their role in HR. In their turn, HR departments are not able to participate in the strategic decision-making process in organizations.

Hence, in the Vietnamese context, HRM is normally considered as a set of philosophies, policies, procedures, programs, and actions related to attracting, training, developing, and retaining people to achieve both the organization's objectives and employee satisfaction (Tran, 2015).

\subsection{Human resource management practices}

According to Stone (2008) and Noe et al. (2016), HRMPs involve acquisition, development, reward and motivation, maintenance and departure of an organization's human resources through key activities such as job analysis and design, human resource planning, recruitment, selection, training, human resource development, career planning and development, employee motivation, performance management, compensation, benefits, and employee relations.

The Michigan University's human resource management model by Fombrun, Tichy, and Devanna (1984) comprises four core functions of HRM which are selection, performance appraisal, rewards, and development. Under these names of HRM functions, practices were quite diversified such as:

Selection matching people to jobs, so called attracting, recruitment, staffing, placement, etc.

Performance appraisal involving performance evaluation, later is widen to include performance review, performance management, etc.

Rewards emphasizing importance of pay in motivating towards performance results; this practice may have other name in research such as compensation, rewards, and benefits.

Development of skilled individuals, so called training, personal/organizational development, or career development, etc.

From a practitioner viewpoint, Society of Human Resource Management - SHRM (2015) reported that HRM practices nowadays involve compensation and benefits, business leadership and strategy, diversity, employee relations, ethics and corporate, social responsibility, organizational and employee development, talent management, and technology. Meanwhile, 
according to Chartered Institute of Personnel and Development - CIPD (2015), three top current priorities for HR functions in 2014 were employee engagement, managing change and cultural transformation, and managing performance.

\subsection{Theoretical framework to study human resource management practices}

A theoretical framework to study HRMPs will conceptualize their roles and interrelationships to carry out HRM functions. The purpose of such framework is to provide researchers with guidance for identifying the roles of HRMPs and their relationships in research model. This framework also helpfully provides managers with trendy ways towards HRM effectiveness and hence to recognizing necessary competencies, functions, a dual responsibility of HR department and line managers. The management team can set policies as well as the priority of HRMPs accordingly.

In general, with respect to the HRM model by Michigan University, there are three key questions for which HRM has to deliver answers to the firm: How to attract the right HR? How to increase their productivity and develop their competencies? How to recognize, reward, and retain competent and high performance employees? That was why many researches have applied all four functions mentioned above into HRMPs as in Katou (2008), Joseph and Dai (2009), Bhanugopan (2013), Šikýř (2013) or in the review of Aggarwal \& Bhargava (2009). These practices indicated that there was an emphasis on the technical side - in other words, the "hard" side of HRM functions. Furthermore, less mentioned were some other "hard HRMPs" such as promotion, job design, etc. Normally, the HR department is the owner of this hard group. Depending on research purposes, characteristics of regional or industrial culture, some studies further mention these hard practices such as promotion (Singh, 2004; Katou, 2008), job design (Singh, 2004; Katou, 2008, Šikýř, 2013), and employee relations (Ying, 2005), etc.

Besides, HRMPs also cover the "soft" side of HRM functions such as teamwork, communication, employee involvement, motivation, etc. In this paper, we name them "soft HRM practices." Teamwork and communication were recognized by Le and Truong (2005) and Katou (2008), while employee involvement was studied in Singh (2004), Katou (2008), and motivation in Šikýr (2013).

Among hard and soft groups, some HRMPs such as job analysis, work design, recruitment and selection, placement, training and development, performance appraisal, compensation and benefits, employment law and compliance, etc. used to be applied for a long time as the basis of any HRM system. They are called "traditional" HRMPs.

With the shift of HRM responsibility to line managers, especially, the development of a new role of HRM as a business partner, to support globalization and internalization, HR department today is expected to be able to integrate its work not only inside the organization but also towards outside customers, investors, and community leaders. The mutual responsibility for HR department and line managers will enhance business leadership and strategy, as well as focus more on customers, i.e. HR from the out-side in (Ulrich et al., 2012). Thus, those organizational wide practices such as employee engagement, organization design, talent management, cultural transformation, retention, etc. are considered under HRM functions. We have called them "contemporary" HRMPs to distinguish them from those "traditional" ones above. 


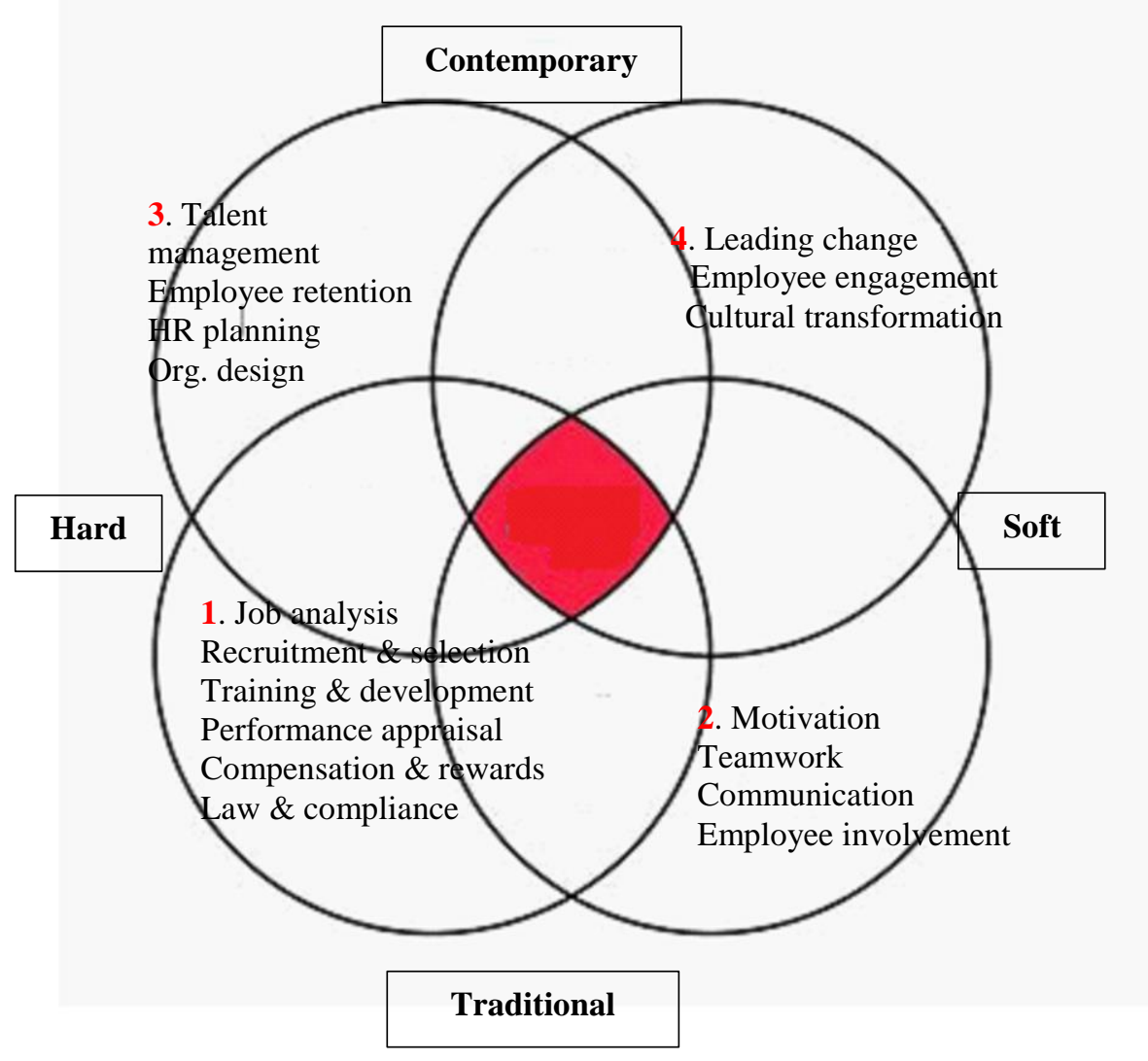

Figure 1. A theoretical framework for classification of HRMPs

From both academic and practical points of view, HRMPs can therefore be categorized into four groups (see Figure 1):Traditional- $h$ ard HRMPs: job analysis, work design, recruitment and selection, placement, training and development, performance appraisal, compensation and benefits, employment law and compliance, etc.

Traditional-soft HRMPs: motivation, teamwork, communication, employee involvement, etc.

Contemporary-hard HRMPs: organization design, HR planning, employee retention, talent management, etc.

Contemporary-soft HRMPs: leading change, employee engagement, cultural transformation, etc.

Contemporary HRMPs, both hard and soft, are still emerging. Scope of such practices is expected to continuously widen in the future.

As this is an evolution of HRM, boundaries among the four groups of HRMPs are not discrete. The contemporary ones cannot be implemented unless the traditional ones are effectively in place. Soft practices can work well only when hard practices are implemented in advance. The contemporary-hard HRMPs are built based on so-called "systematic infrastructure" by the traditional-hard one. The traditional-soft HRMPs provide a basis of developing the contemporary-soft ones.

As result, this theoretical framework reflects 
a practical approach to categorization and correlations among HRMP groups in firms. Depending on developmental periods and in respect of management approach in particular firms, specific HRMPs in each circle of the framework will be different. For example, in most of multinational companies in Vietnam currently, such HRMPs as "Organizational design", "HR planning, "Employee engagement", or "Cultural transformation" are working well. Meanwhile, in domestic firms, especially SMEs and SOEs, these contemporary HRMPs are seldom.

Thus, to test this framework in Vietnam in the mean time, not all of the HRMPs above were put into research. Only the HRMPs which are popular across different types of firms in Vietnam were selected from each circle of the framework.

From the first circle, i.e. the traditional-hard HRMPs, four traditional dimensions of hard HRMPs were selected from the literature review with respect to Vietnamese context: Recruitment and selection, Training and development, Performance appraisal, Compensation and rewards.

Motivation was mentioned in recent researches such as Stone (2008), Sikyr (2013). As a common situation in centrally planned economies, many managers had focused on mandating rather than motivating. When moving to market orientation, managers have recognized the value of employee motivation. In addition, the Vietnamese economy has not gone through the economic recession since 2011. Thus during this period, managers have had to encourage people, not just direct or command them. Thus, "Motivation" was selected from the second circle, i.e. the traditional-soft HRMPs, for examining in this research.

The fact that Vietnam has participated in the WTO, AEC, and TPP causes serious competition even in the domestic market. Improving productivity and business effectiveness has become the key to the survival of Vietnamese firms. This situation forces managers in these firms to change their mindset and practices in order to motivate their people, and to attract and retain talent. In addition, the war for talent has become more serious. Consequently, talent management has become a hot topic in Vietnam in recent years. Thus "Talent management," which was also supported by Šikýř (2013), taken from the third circle of the contemporary-hard practice of HRM, was selected for this research.

Leading change was mentioned in the research by Alfes, Truss \& Gill (2010) and discussion on "HR as a change agent" by Ulrich et al. (2009) and then reinforced by Ulrich et al. (2012). The transformation from a centralplanned economy toward a market-oriented one has forced Vietnamese firms to change radically. As promoted by seniority rather than by competencies, many managers do not want to change. Still, many HR policies, such as salary system and welfare, are being directed by the central government. In such situations, HRM is required to move strongly forward to get along well with business moving. HR practitioners are facing challenges from the role of change agents. Thus, "Leading change" from contemporary-soft HRMPs was suggested to be examined in this research.

In summary, this research selectively focuses on seven dimensions of HRMPs: four traditional-hard, one traditional-soft, one contemporary-hard, and one contemporary-soft (see Table 1). Then HRMP concept is proximately described by these seven dimensions. Thus, the first hypothesis of this research is:

Hypothesis H1: HRMPs are interrelated through a multi-dimensional construct. 


\section{Table 1}

Key concepts of HRMP in the research model

\begin{tabular}{|c|c|c|}
\hline Construct & Definitions & Literature \\
\hline $\begin{array}{l}\text { Recruitment } \\
\& \text { selection }\end{array}$ & $\begin{array}{l}\text { The process of seeking and attracting qualified } \\
\text { applicants for job vacancies through selection } \\
\text { techniques and policy. }\end{array}$ & $\begin{array}{l}\text { Fombrun et al (1984), } \\
\text { Tran (2015) }\end{array}$ \\
\hline $\begin{array}{l}\text { Training \& } \\
\text { development }\end{array}$ & $\begin{array}{l}\text { Build individual capability and knowledge to meet } \\
\text { current and strategic requirements of the organization } \\
\text { and personal career development. }\end{array}$ & $\begin{array}{l}\text { Fombrun et al (1984), } \\
\text { Tran (2015) }\end{array}$ \\
\hline $\begin{array}{l}\text { Performance } \\
\text { appraisal }\end{array}$ & $\begin{array}{l}\text { A system to record, fairly evaluate employee } \\
\text { performance, with an aim to improving individual } \\
\text { performance and hence achieving firm's objectives. }\end{array}$ & $\begin{array}{l}\text { Fombrun et al (1984), } \\
\text { Tran (2015) }\end{array}$ \\
\hline $\begin{array}{l}\text { Compensation } \\
\& \text { rewards }\end{array}$ & $\begin{array}{l}\text { A system of payment that is fair and focused on job } \\
\text { requirements, employee competencies and individual } \\
\text { and organizational performance }\end{array}$ & $\begin{array}{l}\text { Fombrun et al (1984), } \\
\text { Tran (2015) }\end{array}$ \\
\hline Motivation & $\begin{array}{l}\text { Policies and action plans to make employees feel happy } \\
\text { and inspired in their jobs; building desire to make } \\
\text { efforts and to give their best contributions to the } \\
\text { organization. }\end{array}$ & $\begin{array}{l}\text { Robbins, S. (1986), } \\
\text { Stone (2008), Šikýr } \\
(2013) .\end{array}$ \\
\hline $\begin{array}{l}\text { Leading } \\
\text { change }\end{array}$ & $\begin{array}{l}\text { Act as a role model leader, maximizing dynamic and } \\
\text { positive forces for stimulating creativity, diversity, } \\
\text { learning and growth. }\end{array}$ & $\begin{array}{lr}\text { Ulrich et al. (2009), } \\
\text { Milkovich } \\
\text { Boudreau } \\
\text { (2004),CIPD } & \text { (2015), } \\
\text { Tran (2015) } & \end{array}$ \\
\hline $\begin{array}{l}\text { Talent } \\
\text { management }\end{array}$ & $\begin{array}{l}\text { A system to ensure that the organization has the right } \\
\text { resources, capability and talents to achieve its } \\
\text { immediate and strategic objectives. }\end{array}$ & $\begin{array}{l}\text { CIPD (2015), Šikýr } \\
(2013) .\end{array}$ \\
\hline
\end{tabular}

\subsection{Firm's business performance}

According to Franco-Santos (2007), before the 1980s, firm's business performance was measured merely by financial results. Since the 1980s, business performance has been measured additionally by a variety of indicators in order to sufficiently reflect the actual performance. The Balanced-scorecard system (BSC) by Kaplan \& Norton (1992) has contributed significant pace of performance measurement system, both in theory and in practice. Such "balanced" system captured 4 key measurable dimensions which cover a firm's business performance: finance, 
market, internal processes, and learning \& growth. In Vietnam, BSC system has not been applied widely.

Hence, in order to work across types of firms, this research selectively measures business performance based on employees' evaluation of their firm's finance and market results (Chand and Katou, 2007; Mansour, 2015), in which:

Financial results were measured through perceived achievement of goals in revenues and profit;

Market results were measured through perceived achievement of goals in market share increase and customer satisfaction on companies' products and services.

The two groups of indicators above are the most popular in recent researches. Oladipo \& Abdulkadir (2011) also proposed that business performance should be measured by the growth rates of revenue or sales, financial power (e.g. liquidity, reserve fund, borrowing capacity, etc.), ROE, ROA, and profit. Guest et al. (2003) measured business performance by productivity and financial results. Particularly, productivity was defined by sales per employee, and financial results by profit per employee.

\subsection{Relationships between HRM practices and firm's business performance}

Effective HRMPs bring positive HR outcomes such as high competencies, satisfaction, high responsibility and commitment to the organization. Satisfied employees are more likely to make customers satisfied, as a result, business performance of the firm will improve. Therefore, relationship between HRM and firm performance has been tested in many researches, with diversified respondents and in various contexts such as Fey et al. (2000) in Russia, Park et al (2003) in Japanese MNC's, Singh (2004) in India, Joseph and Dai (2006) in Abidjan, Katou (2008) in Greece, Sikýr (2013) in Czech, etc. In Vietnam, research also showed that effective HRM practices can lead to higher organizational performance. Previous studies were conducted in different industries with different types of ownership such as Le and Truong (2005), Ying (2005), Pham (2011), Nguyen and Ngo (2012).

Thus, in order to examine their significant importance to firms' business performance, our main hypothesis is:

Hypothesis H2: HRMPs positively affect the firms' business performance.

\section{Methods}

\subsection{Research design}

This research applied a mixed methodology to explore the current HRM practices and their importance in Vietnamese firms.

Preliminary research was conducted using qualitative methods to explore the current HRMPs in Vietnam and their contribution to the business performance of Vietnamese firms. A total of nine managers and 12 employees were interviewed concerning the theoretical framework and their practices. The results were used to develop a research framework for HRMPs in the Vietnamese context and to select constructs for which data can feasibly be collected across different types of firms in Vietnam.

The main research was conducted quantitatively, using a survey, involving selfdirected questionnaires and face-to-face contact.

\subsection{Sample and data collection}

Respondents were managers and HR specialists working for firms in Ho Chi Minh city, Vietnam. Convenient sampling methods 
were applied. The data include 635 valid responses from 388 firms, across different industries. The response rate to the survey was approximately 43 per cent. Mean scores we re calculated for a firm when more than one response was received from the same firm (i.e., scores were aggregated).

\subsection{Measurement of latent variables}

This research developed a set of valid and reliable instruments to measure seven HRMP constructs, including recruitment and selection, training and development, performance management, compensation, leading change, motivation, and talent management. Observable variables to operationalize these constructs are based on previous research by Tran (2015, pp. 409-411). Each of the HRMP constructs was measured using three observable variables (see Table 2).

The firms' business performance is measured using four observable variables regarding perceived performance in terms of revenue, profit, customer satisfaction, and market share. All variables were scored on a seven-point Likert scale, with responses ranging from one (strongly disagree) to seven (strongly agree).

\subsection{Data analysis methods}

First, the measurement model was tested on the complete data set using exploratory factor analysis employing SPSS 20.0. The data exhibited univariate kurtosis and skewness characteristics within the range $[-1,+1]$. Thus, the maximum likelihood method was used to determine the underlying factor structures (Muthen and Kaplan, 1985).

Then, confirmatory factor analysis (CFA) was employed, using AMOS 20 to further investigate the latent structure of the factors and to test the measurement model. This tests the construct validity with uni-dimensionality, reliability, convergent validity, discriminant validity, and predictive validity (Garver \& Mentzer, 1999). CFA is used in this stage because it allows testing of the theoretical structure of the construct measurements, which is hypothesized to consist of multiple subconstructs, that is, latent constructs, with less bias errors (Steenkamp \& van Trijp, 1991). This method assists in confirming the dimensions of the HRMPs and those of business performance, with their respective measurement scales.

In order to test the hypotheses in such a structure of relationships, we tested the research model through structural equation modelling (SEM), using AMOS 20. The SEM method is effective when testing latent constructs that are being measured with multiple items. SEM has advantages over a traditional method such as multiple regression because it can calculate measure errors. SEM assists in combining latent constructs and measuring, testing and connecting them with the dependent variable in the theoretical model (Arocas \& Camps, 2008). Thus, it was applied in this research to measure the multi-dimensional construct of HRM practices.

\section{Data analysis and results}

\subsection{Measurement validation}

Firstly, the CFA for measurement test of HRMPs produces model fit with: $\chi 2$ [182] = 342.144; $\mathrm{p}=0.000 ; \mathrm{GFI}=0.923 ; \mathrm{TLI}=0.964$; CFI=0.969; RMSEA=0.048. In addition, all factor loadings were fairly high as $>0.586$ and significant $(\mathrm{p}<0.001)$. These findings indicate that those scales measuring the seven dimensions of HRM practices were uni-dimensional.Withinmethod convergent validity was achieved based on the standard by Steenkamp and Trijp (1991). The results supported the conclusion that seven- 
dimensional scales of HRM practices, including recruitment and selection, training and development, performance appraisal, compensation and rewards, leading change, motivation, and talent management are relevant to the Vietnamese context.

Secondly, the CFA for Business performance shows that it is a two-dimensional construct: financial results and market result, with two observable items for each. Scale of business performance produces model fit with: $\chi^{2}$ [1] $=$ 1.736; $\mathrm{p}=0.000 ; \quad$ GFI $=0.998 ; \quad \mathrm{TLI}=0.994$; $\mathrm{CFI}=0.999 ; \mathrm{RMSEA}=0.044$.

See Table 2 for CFA item loadings, composite reliability, and average variance extracted of the scales validated.

Finally, the overall measurement model produced model fit with: $\chi^{2}$ [202] $=354.693$; $\mathrm{df}=202 ; \mathrm{p}=0.000 ; \quad \mathrm{GFI}=0.927 ; \quad \mathrm{TLI}=0.966$; $\mathrm{CFI}=0.972 ; \quad \mathrm{RMSEA}=0.044$. All composite reliability $(\mathrm{Pc})$ ranged from 0.740 to 0.932 ; Variance extracted (VE) ranged from 0.517 to 0.793 . Factor loading ranged from 0.765 to 0.889 . All correlations had estimate $\mathrm{r}$ from 0.405 to 0.809 ; and $\mathrm{p}<0.000$, proving the discriminant validity of the constructs. The correlations between constructs, together with their standard errors, indicate that they were significantly different from unity, thus, supporting the construct discriminant validity (Steenkamp \& Trijp, 1991). Therefore, hypothesis H1 is accepted. The HRMPs are measured through seven interrelated dimensional constructs. In other words, HRMPs are composed of seven dimensions.

\subsection{Results}

The Research model produced model fit with: $\chi^{2}[222]=407.743 ; \mathrm{df}=222 ; \mathrm{p}=0.000 ; \mathrm{GFI}=$ 0.917; TLI=0.962; CFI=0.967; RMSEA $=0.046$ (see Figure 2). A positive relationship between HRMPs and business performance was found $(0.65)$ with $\mathrm{p}<0.001$. The results hence indicate that HRMPs are key factors predicting the business performance of firms. HRMPs can explain 43 percent of the variance of business performance. The squared multiple correlations for all variables ranged from 0.428 to 0.838 . Therefore, hypothesis $\mathrm{H} 2$ is accepted. These HRMPs affect positively on business performance of Vietnamese firms. 


\section{Table 2}

Mean, standard deviation, and standardized CFA factor loading of items

Mean $\begin{gathered}\text { Std. } \\ \text { Deviation }\end{gathered} \quad \begin{gathered}\text { Standardized } \\ \text { loadings }\end{gathered}$

HRM practices: Composite reliability $(\mathrm{Pc})=0.9317$; Average variance extracted $(\mathrm{AVE})=0.6627$

1. Recruitment: Composite reliability $(\mathrm{Pc})=0.7594$; Average variance extracted $(\mathrm{AVE})=0.5174$

$\begin{array}{lllll}\text { Selection criteriaare standardized according to job } & 4.75 & 1.425 & 0.586\end{array}$ requirements

$\begin{array}{llll}\text { The recruitment process is relevant } & 4.6 & 1.387 & 0.815\end{array}$

$\begin{array}{llll}\text { There is good collaboration between line managers and HR } & 4.5 & 1.436 & 0.735\end{array}$ department in the selection process

2. Training \& development: Composite reliability $(\mathrm{Pc})=0.8735$; Average variance extracted $(\mathrm{AVE})=0.6983$

$\begin{array}{lllll}\text { Training design and implementation aligns with the firm's } & 4.94 & 1.433 & 0.755\end{array}$ strategic objectives

$\begin{array}{lllll}\text { Employees are provided with training for knowledge and } 4.34 & 1.575 & 0.839\end{array}$ skills to carry out their tasks

$\begin{array}{llll}\text { Training programs are of high quality } & 4.44 & 1.544 & 0.907\end{array}$

3. Performance appraisal: Composite reliability $(\mathrm{Pc})=0.8211$; Average variance extracted $(\mathrm{AVE})=0.6064$

$\begin{array}{llll}\text { Employees receive sufficient feedback and counseling based on } & 4.48 & 1.326 & 0.688\end{array}$ their performance

The performance appraisal system in this firm focuses on $4.46 \quad 1.416 \quad 0.798$ enhancing employee performance

$\begin{array}{lllll}\text { The performance appraisal system in this firm is fair and } & 4.23 & 1.408 & 0.843\end{array}$ accurate

4. Compensation: Composite reliability $(\mathrm{Pc})=0.8773$; Average variance extracted $(\mathrm{AVE})=0.7046$

$\begin{array}{llll}\text { Payment in this firm is fair } & 4.55 & 1.511 & 0.825\end{array}$

$\begin{array}{lllll}\text { Compensation in this firm is based on job requirements and } & 4.7 & 1.521 & 0.878\end{array}$ employees' competencies

$\begin{array}{llll}\text { Employee income reflects performance results } & 4.58 & 1.605 & 0.815\end{array}$

5. Leading change: Composite reliability $(\mathrm{Pc})=0.8313$; Average variance extracted $(\mathrm{AVE})=0.6219$ 


\begin{tabular}{lccc}
\hline & Mean & $\begin{array}{c}\text { Std. } \\
\text { Deviation }\end{array}$ & $\begin{array}{c}\text { Standardized } \\
\text { loadings }\end{array}$ \\
\hline There is frequent encouragement to improve performance. & 4.63 & 1.245 & 0.754 \\
& & & 1.367 \\
Change efforts are encouraged & 4.81 & 0.83 \\
$\begin{array}{l}\text { Opportunities to apply improvement initiatives are open to all } \\
\text { employees }\end{array}$ & 4.69 & 1.366 & 0.781 \\
\hline
\end{tabular}

6. Motivation: Composite reliability $(\mathrm{Pc})=0.8846$; Average variance extracted $(\mathrm{AVE})=0.7187$

$\begin{array}{lllll}\text { There are programs in place that make employees feel } & 4.3 & 1.257 & 0.83\end{array}$ motivated in their jobs

Managers pay attention to how employees feel at work.

$4.37 \quad 1.322 \quad 0.856$

Motivation programs in this firm are effective

$\begin{array}{lll}4.47 \quad 1.375 & 0.858\end{array}$

7. Talent management: Composite reliability $(\mathrm{Pc})=0.8816$; Average variance extracted $(\mathrm{AVE})=$ 0.7129

Programs to attract talent work well

$4.23 \quad 1.46 \quad 0.814$

Programs to retain talent work well

$4.31 \quad 1.435 \quad 0.866$

Programs to develop talent work well

$4.4 \quad 1.442 \quad 0.851$

Business performance: Composite reliability $(\mathrm{Pc})=0.7660$; Average variance extracted $(\mathrm{AVE})=$ 0.6245

1. Financial results: Composite reliability $(\mathrm{Pc})=0.8845$; Average variance extracted $(\mathrm{VE})=$ 0.7936
Achieve revenue target
$4.86 \quad 1.411$
0.83
Achieve profit target
$4.97 \quad 1.401$
0.95

2. Market results: Composite reliability $(\mathrm{Pc})=0.7405$; Average variance extracted $(\mathrm{AVE})=$ 0.5893
Achieve market share target
4.77
1.273
0.82
In general, customers satisfy with the firm's products/services
4.86
1.207
0.71
Valid N (list wise) 


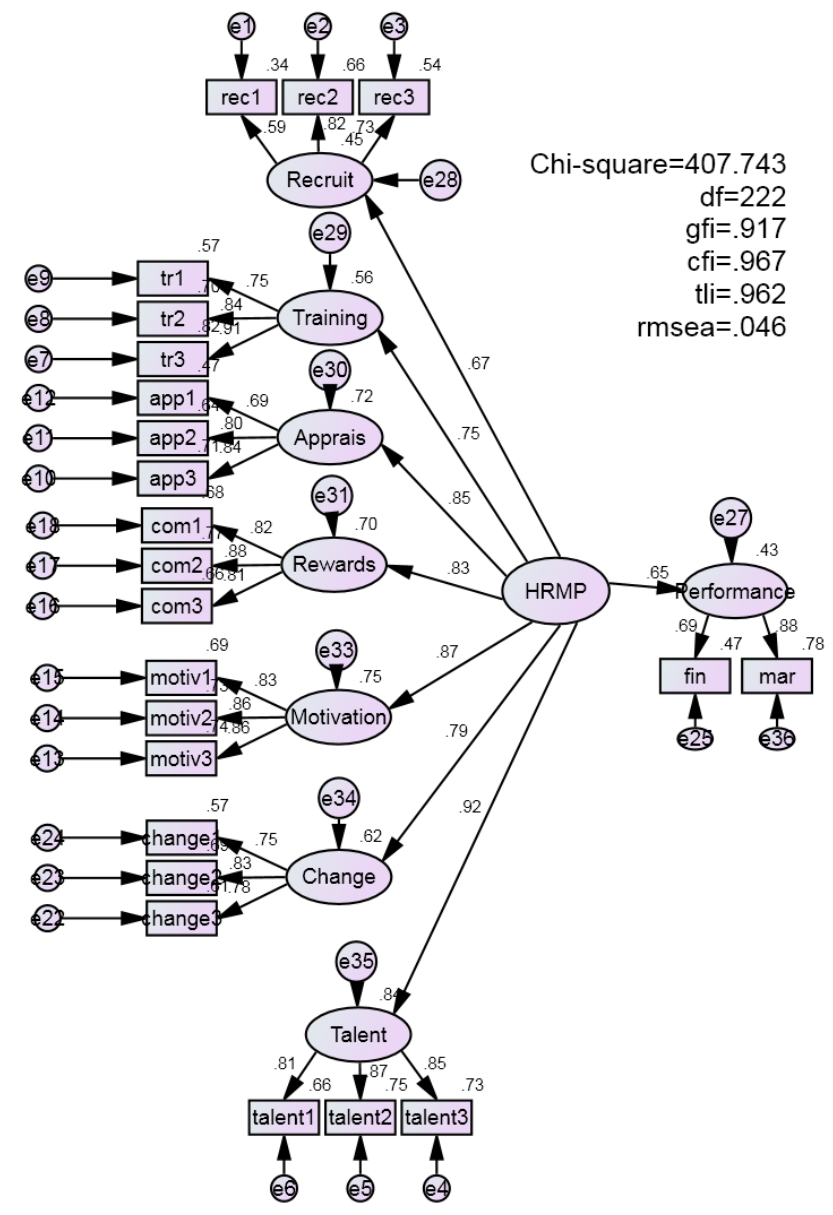

Figure 2. Impact of HRMP dimensions on firm's business performance

As result, HRMPs in Vietnam are composed of seven dimensions with tested construct validity and significant impact on the firm's business performance.

\section{Traditional-hard dimension:}

Recruitment and selection, Training and development, Performance appraisal, Compensation and rewards. These HRMP dimensions comply with many previous studies in Vietnam.

Traditional-soft dimension: Motivation. The motivational practices require insight, understanding and cross-functional collaboration. They represent big challenges to an HR department. They also require a big change in mindset of line managers about their role and responsibility in HRM.

Contemporary-hard dimension: Talent management. Practices in talent management reflect a change in managers' mindset on the important role of talents to firm performance. Priority in HR policies is set for talents. Vietnamese firms today invest more in attracting, developing and retaining talents.

Contemporary-soft dimension: Leading change. Following Ulrich's model about "HR as change agent", leading change practices in HRM are recognized in increasingly important to 
improve the HR quality for partnering with the business operations.

\section{Discussion and implications}

\subsection{Theoretical discussion and implications}

In previous studies in Vietnam, except in Pham (2011), equitized SOEs in Vietnam are still subject to government control, so only traditional HRMPs could be recognized. Le and Truong (2005) recognized some emerging HRM practices such as communication (belong to the factor Information exchange) and retention management. However, an important function of HRM which is recruitment-selection was not examined.

Then, Ying (2005) qualitatively analyzed seven manufacturing firms in Vietnam to identify work relations, employment relations, and employee involvement as key dimensions of HRM practices. This is an exploratory understanding of the implementation of HRM practices. Beside traditional-hard HRMPs, one soft dimension of traditional group, which is employee involvement, was identified. Nguyen and Ngo (2012) in Hanoi mentioned three dimensions of traditional-hard HRMPs, including training, performance appraisal, and incentive compensation which seemed to be typical for SMEs in Vietnam. No contemporary practices were discussed.

Findings of this research close some gaps in previous researches in Vietnam. Relevant concepts of HRMPs to Vietnamese firms are presented in a framework which encourages right awareness about the changing role of HRM in the managerial circles. HRM should be conceived and applied properly in Vietnamese firms to replace the old concept of personnel management which still exists in many SOEs and SMEs.
It is an improvement in comparison to the study by Ying (2005) in which HRMPs in Vietnamese firms depended much on the level of government, labor union, and foreign capital involvement. The improvement is on proactive HRM starting from how to recruit and select the right people to how to retain them through development and compensation.

\subsection{Practical discussion and implications}

The framework of four groups of HRMPs suggested in this paper implies that there is a need to design appropriate training programs for both HR professionals and line managers in order to effectively carry out them.

More than ten years after the research by Le and Truong (2005), there are profound changes in Vietnamese economy with its participation in WTO and TPP that requires transformations in both mindset and practices of managers. Our research finds that the emergence of traditionalsoft and contemporary-hard HRMPs is inevitable to firm's business performance. Managers across functions should be aware of this trend and well prepared in terms of competencies to implement these practices.

The confirmatory results of HRMPs' measurement model imply that HRMPs in Vietnam are following the world trend in HRMPs. Traditional-hard HRMPs are not enough if firms want to improve their business performance through effective HRM. It indicates that HRMPs in Vietnam are moving beyond traditional functions of $\mathrm{HR}$ department and closer to the change agent role and hand-in-hand with line managers in talent management. Such traditional-soft HRMPs as motivation and leading change and the contemporary-hard HRMPs as talent management are practically appropriate to the Vietnamese context.

Investing in such contemporary HRMP dimensions as Talent management and Leading 
change will lead to better business performance, in both competitiveness and sustainability. However, they will also challenge both HR department and line managers in a need for more collaboration as business partners, and to improve their HR competencies.

\subsection{Implication for a roadmap of HRMPS' evolution in Vietnam}

It would be more feasible when soft HRMPs are developed based on a well-designed system of hard HRMPs and contemporary practices based on traditional practices. This roadmap fits the Vietnamese culture which favors an incremental change over a radical change. The two types of change are not mutually exclusive but reciprocal.

A roadmap of HRMPs evolution in Vietnam is suggested to picture out a development path from traditional hard HRMPs, to traditional soft HRMPs, then contemporary hard ones, and finally contemporary soft group. The roadmap is drawn on the theoretical framework of this research (see Figure 3).

Typically in Vietnam, enterprises which become aware of the significance of HRMPs normally start to invest much in the hard side of the traditional ones as tested in this research. Then traditional soft HRMPs will be upgraded. Currently, Motivation is recognized to be the first consideration in this dimension.

In the efforts towards contemporary dimension, with the effect of Motivation, Talent management is significant to business impact. It is expected that more contemporary hard HRMPs will be developed as the next stage. To Vietnamese enterprises, the technical side is always the first in learning.
The high-level in the evolution of HRMPs is the contemporary soft dimensions. As currently Leading change is recognized significantly. It is expected there will be more HRMPs in this group if such contemporary-hard HRMPs as Talent management effectively works.

\section{Conclusion and limitations of this research}

\subsection{Summary}

HRMPs in Vietnam are composed of seven dimensions with tested construct validity. Beside the traditional dimensions of HRMP such as recruitment and selection, training and development, performance appraisal, compensation and rewards, as the hard ones, and motivation as the soft one. The contemporary dimensions which are significant in current Vietnamese context are talent management, as the hard one, and leading change as the soft one.

With this new framework of HRMPs, compared with previous studies in Vietnam, in a different economic context, it is nevertheless still true that HRMPs have a significant impact on a firm's business performance. This proves that people must be the vital key to the firm's success.

\subsection{Contributions of the study}

Firstly, this research suggests relevant concepts of HRMPs to Vietnamese firms. Our research updates the situation in Vietnam and provides clearer concepts about HRMPs based on classifying them into hard vs. soft and traditional vs. contemporary groups. The framework of HRMPs in this study also supports the recent concept of human resource management. 


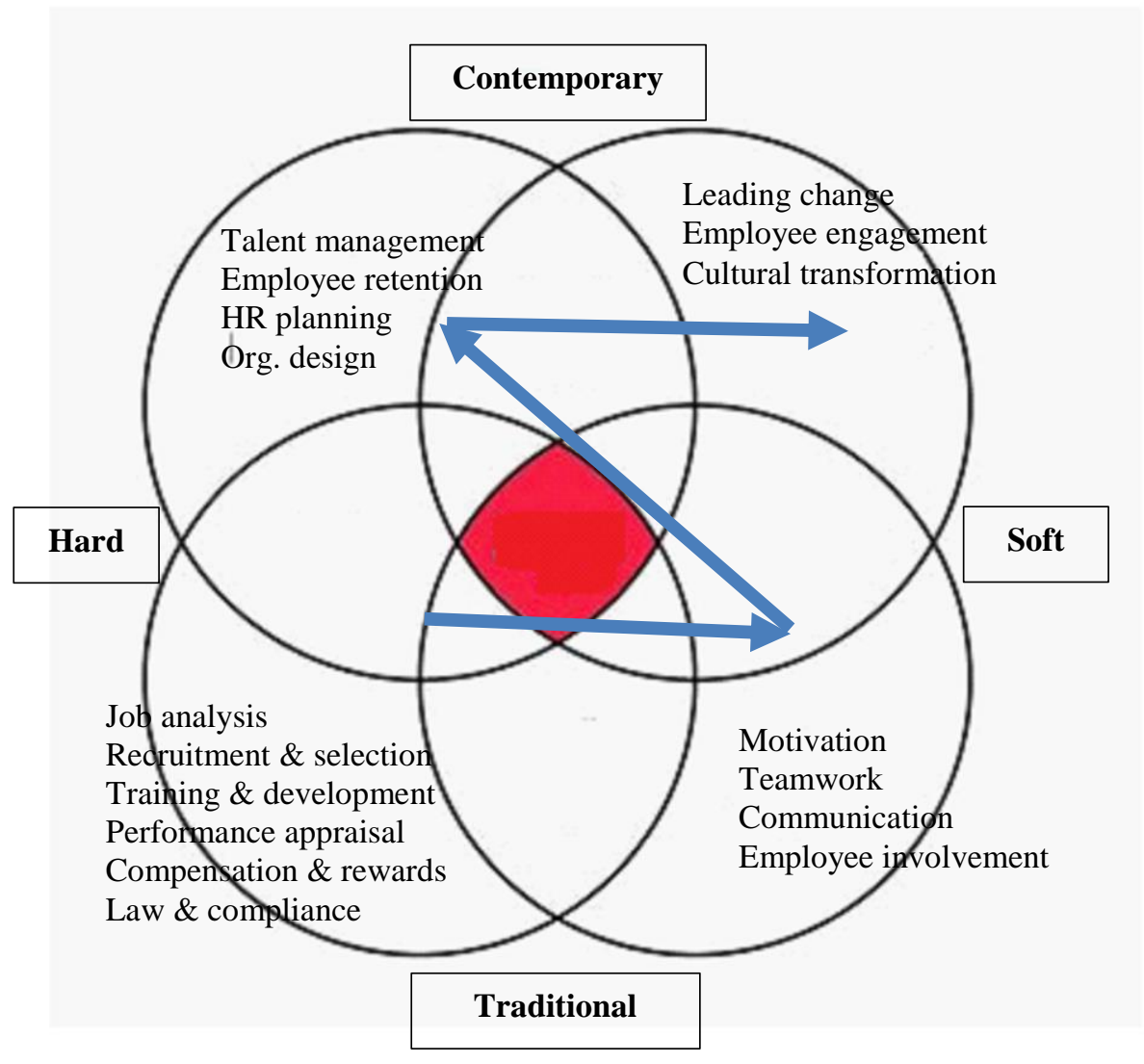

Figure 3. A suggested roadmap for HRM practices evolution in Vietnamese firms

Secondly, the research contributes to HRM field of study with valid measurement scales of HRMPs that would be significant in the Vietnamese context.

Thirdly, this research has found significant influences of HRMPs on the firm's business performance. The key is which specific HRMPs should be conducted in particular periods of Vietnamese economy in order to bring in the most effective performance.

Fourth, based on these findings, firms in such developing countries as Vietnam can learn how to set a roadmap to invest and upgrade their HRMPs following the world trend. Then, a roadmap of HRMPs development in Vietnam is suggested as a reference for human resource managers and top management to consider in strategic HRM. Human resource directors can benchmark this roadmap and envisage the evolution process of HRMPs in their organizations. Accordingly, they can determine and distinguish responsibilities of HR department from line managers in implementing HRMPs meanwhile encouraging their collaboration in HRM.

\subsection{Limitations and future research}

As the sample data was collected by the convenient method and in only firms in Ho Chi Minh city, Vietnam, the generalization of the suggested framework and roadmap of HRMPs evaluation for all firms in Vietnam is not sufficiently confident. The model needs further 
replication in other regions in Vietnam and critical evaluation to provide reliable insights.

This research did not measure organizational design, employee engagement, and cultural transformation as reviewed in our literature of contemporary HRMPs. In the next few years, following the roadmap of HRMPs' evolution, these factors will become more popular with Vietnamese firms and might be included and tested in a future framework.
Furthermore, business performance was measured in perceived scales of an attitude survey. In such an environment of insufficient information about firm performance as in Vietnam, except those big ones on the stock market, it is still impossible to access fact data about firm performance. Therefore, the figures reflect managers' perceptions, not actual firm performance such as objective indicators

\section{References}

Aggarwal, U., \& Bhargava, S. (2009). Reviewing the relationship between human resource practices and psychological contract and their impact on employee attitude and behaviors: A conceptual model. Journal of European Industrial Training, 33(1), 4-31.

Alfes, K., Truss, C., \& Gill, J. (2010). The HR manager as change agent: Evidence from the public sector. Journal of Change Management, 10(1), 109-127.

Arocas, R. L., \& Camps, J. (2008). A model of high performance work practices and turnover intentions. Personnel Review, 37, 26-46.

Bhanugopan, R., Aladwan, K., \& Fish, A. (2013). A structural equation model for measuring human resource management practices in the Jordanian organizations. International Journal of Organizational Analysis, 21(4), 565-587.

Chand, M., \& Katou, A. (2007). The impact of HRM practices on organizational performance in the Indian hotel industry. Employee Relations, 29(6), 576-594.

CIPD. (2015). HR outlook: Winter 2014-15 - Views of our profession. Retrieved January 20, 2015 from www.cipd.co.uk/hroutlook

Fey, C. F., Björkman, I., \& Pavlovskaya, A. (2000). The effect of human resource management practices on firm performance in Russia. International Journal of Human Resource Management, 11(1), 1-18.

Fombrun, C., Tichy, N. M., \& Devanna, M. A. (Eds.) (1984). Strategic human resource management. Wiley, New York.

Franco-Santos, M., Kennerley, M., Micheli, P., Martinez, V., Mason, S., Marr, B., ... \& Neely, A. (2007). Towards a definition of a business performance measurement system. International Journal of Operations and Production Management, 27(8), 784-801.

Garver, M., \& Mentzer, J. (1999). Logistics research methods: Employing structural equation modeling to test for construct validity. Journal of Business Logistics, 20(1), 33-52.

Guest, D. E., Michie, J., Conway, N., \& Sheehan, M. (2003). Human resource management and corporate performance in the UK. British Journal of Industrial Relations, 41, 291-314.

Joseph, K. E., \& Dai, C. (2009). HRM practices and organizational performance: An empirical analysis. International Journal of Business and Management, 4(8), 117-127.

Katou, A. A. (2008). Measuring the impact of HRM on organizational performance. Journal of Industrial Engineering and Management, 1(2), 119-142.

Le, C. T., \& Truong, Q. (2005). Antecedents and consequences of dimensions of human resource management 
practices in Vietnam. The International Journal of Human Resource Management, 16(10), 1830-1846.

Losey, M., Meisinger, S., \& Ulrich, D. (Eds.) (2005). The Future of human resource management: 64 thought leaders explore the critical HR issues of today and tomorrow. Hoboken, Wiley, NJ.

Mansour, M. (2015). The practice of strategic human resource management in a developing country. European Online Journal of Natural and Social Sciences, 4(3), 500-517.

Milkovich, G. T., \& Boudreau, J. W. (2004) Personnel/human resource management: A diagnostic approach. Richard Irwin, Illinois.

Muthen, B., \& Kaplan, D. (1985). A comparison of some methodologies for the factor analysis of nonnormal Likert variables. British Journal of Mathematical and Statistical Psychology, 38(2), 171-189.

Nguyen, M. N., \& Ngo, V. T. (2012). Effects of human resource management on business performance of small and medium size manufacturers in Hanoi, Vietnam. Australian Journal of Business and Management Research, 2(6), 47-54.

Noe, R., Hollenbeck, J., Gerhart, B., \& Wright, P. (2016). Fundamentals of human resource management (6th Ed.). McGraw-Hill Education.

Oladipo, J. A., \& Abdulkadir, D. S. (2011). Strategic human resource management and organizational performance in the Nigerian manufacturing sector: An empirical investigation. International Journal of Business and Management, 6(9), 46-56.

Park, H. J., Mitsuhashi, H., Fey C. F., \& Björkman, I. (2003). The effect of human resource management practices on Japanese MNC subsidiary performance: A partial mediating model. The International Journal of Human Resource Management, 14(8), 1391-1406.

Pham, L. (2011). Impact of applying human resource management practices on equitized state-owned enterprises' financial performance in Vietnam. Journal of International Business Research, 10(2), 79-90.

Robbins, S. (1986). Organizational behavior: Concepts, controversies, and applications (3rd Ed.). Prentice Hall International Editions.

Šikýř, M. (2013). Best practices in human resource management: The source of excellent performance and sustained competitiveness. Central European Business Review, 1, 43-48.

Singh, K. (2004). Impact of HR practices on perceived firm performance. Asia Pacific Journal of Human Resources, 42(3), 301-317.

Steenkamp, J., \& van Trijp, M. (1991). The use of LISREL in validating marketing constructs. International Journal of Research in Marketing, 8(4), 283-299.

Tran, K. D. (2015). Human resource management (9th Ed.) (in Vietnamese). University of Economics, Ho Chi Minh City, Vietnam.

Ulrich, D., Allen, J., Brockbank, W., Younger, J., \& Nyman, M. (2009). HR transformation: Building human resources from the outside in. McGraw-Hill Education, US.

Ulrich, D., Younger, J., Brockbank, W., \& Ulrich, M. (2012). HR from the outside in: Six competencies for the future of human resources. McGraw-Hill, US.

Ying, Z. (2005). The Asian crisis and the implications for human resource management in Vietnam. The International Journal of Human Resource Management, 16(7), 1261-1276. doi: 10.1080/713999155 